\title{
Video Usage among Secondary School Students during the COVID-19 Pandemic
}

\author{
Nur Syahmina Amalia Ab Razak¹, Rosseni Din²,* \\ ${ }^{1}$ Faculty of Education, Universiti Kebangsaan Malaysia 43600 UKM Bangi, Selangor, Malaysia \\ ${ }^{2}$ STEM Research Center, Faculty of Education, Universiti Kebangsaan Malaysia 43600 UKM Bangi, Selangor, Malaysia
}

Received July 30, 2020; Revised October 26, 2020; Accepted October 30, 2020

\section{Cite This Paper in the following Citation Styles}

(a): [1] Nur Syahmina Amalia Ab Razak, Rosseni Din, "Video Usage among Secondary School Students during the COVID-19 Pandemic," Universal Journal of Educational Research, Vol. 8, No. 11A, pp. 43 - 48, 2020. DOI: 10.13189/ujer.2020.082106.

(b): Nur Syahmina Amalia Ab Razak, Rosseni Din (2020). Video Usage among Secondary School Students during the COVID-19 Pandemic. Universal Journal of Educational Research, 8(11A), 43 - 48. DOI: 10.13189/ujer.2020.082106.

Copyright $\odot 2020$ by authors, all rights reserved. Authors agree that this article remains permanently open access under the terms of the Creative Commons Attribution License 4.0 International License

\begin{abstract}
The COVID-19 pandemic has intensified the already rapid pace of global development, including technological advances. Teachers are therefore required to adapt to, and update themselves on, the types of pedagogy needed to make teaching and learning attractive to students. However, the pandemic outbreak continues to threaten the education system and has closed schools worldwide. Consequently, the education system has changed dramatically, with teaching and learning increasingly being undertaken remotely on digital platforms. Video is one of the tools that can be used during this pandemic phase. This paper identifies secondary school students' perceptions of the use of video in teaching and learning. Data were analyzed using descriptive statistics, Independent t-tests, and Pearson Correlation tests. The findings indicated that the majority of the respondents had positive perceptions of video usage in the classroom. These findings are useful for English teachers and may be useful for other educators in the same field. Because there are different types of students, this study will be beneficial in enabling educators to understand their students' preferences when learning English. Educators can also optimize the use of video to enhance their students' proficiency in the use of English.
\end{abstract}

Keywords Secondary School Students, Teaching Learning with Video, Visual Aids: $21^{\text {st }}$ Century Living, COVID-19 Pandemic

\section{Introduction}

Students lose interest in learning in class when there is no enjoyment to be had [1]. Educators must therefore make an additional effort and utilize technology, rather than depend solely on textbook material. Ebrahimi and Yeo [2] found that $57 \%$ of teachers used technology for education, whereas $39 \%$ of teachers admitted not having received any training in using technology. However, this situation drastically changed because of the COVID-19 pandemic outbreak three months into 2020. On 26 March 2020, UNESCO announced that 1.6 billion students from 165 countries were no longer attending school [3]. Education leaders have therefore had to resort to multiple strategies to ensure the continuation of learning, the most effective of which has been the use of digital technology.

The Malaysian Education Blueprint 2013-2025 [4] is an initiative launched by the Ministry of Education to assist Malaysia in the final part of its journey towards becoming a high-income nation. This blueprint outlines eleven transformational shifts that would be required to accomplish the objective of national education. One of these is to use information and communication technology (ICT) to scale up learning quality across Malaysia to produce creative, independent lifelong learners who achieve highly and are prepared for the challenges of $21^{\text {st }}$ century living.

With videos specifically edutainment video, the teaching and learning process becomes enjoyable and engaging for teachers and students. However, studies [5] found that 
educators continue to rely on traditional methods in the teaching and learning process, rather than use technology such as videos. However, the results of this study indicate that students have more positive attitudes towards the use of video than typical traditional classroom methods and have no problem understanding lessons delivered using videos.

According to another study [6], teachers have begun using videos and multimedia presentations in their classes, as they are an effective method to reach students. For instance, videos help to attract students' attention, generate interest, boost concentration, enhance understanding, and increase the retention of content. This view is supported by the Director of the Academic Development Management Division who stated that, "We should take advantage of the great things technology can bring which were not possible before" [7].

Despite the clear benefits of edutainment videos for both teachers and students, some teachers are reluctant to use it in the classroom. Siti Hadijah [8] stated that this is because they encounter numerous challenges utilizing videos. One of these is that the teacher may fail to arouse students' interest in learning owing to technical problems related to running the video. However, such a problem will sometimes occur and teachers therefore need to have a back-up plan.

The communication process that occurs between humans and computer software, known as interactivity, can help students and teachers manage the flow and pace of the lessons [9]. For instance, teachers can easily pause, play, or rewind the material. Multimedia and visual aids can have a positive effect on students' comprehension of content, helping them to overcome learning difficulties with videos, photos, websites, Smart Boards, and other technological tools [10]. Technology can also be a helpful instrument in the language classroom as it assists teachers to deliver, and students to understand, the lesson better. Furthermore, traditional classes can sometimes bore students as they focus on textbooks and primarily rely on face-to-face interaction in the classroom.

Several studies have been conducted in Malaysia on the use of Facebook, WhatsApp, Twitter, and Telegram as popular learning tools. However, there have been few studies on the use of videos in secondary schools. Moreover, most of the studies that have been undertaken have primarily focused on higher education learners. According to Siew et al. [11], the most commonly, used tools across universities are Facebook, emails, and online self-tests/quizzes/practices. Therefore, this study aimed to explore perceptions of video usage among secondary school students.

\section{Materials and Methods}

This study employed a purposive sampling technique to recruit the participants. Purposive sampling is a non-probability sampling method that is employed when individuals selected for the sample are chosen by the researcher. This technique is also known as judgment, selective, or subjective sampling as the researcher relies on his or her judgment when choosing members of the target population [12]. There are several types of purposive sampling, including heterogeneous purposive sampling, homogeneous purposive sample, typical case sampling, extreme or deviant case sampling, total population sampling, and expert sampling. This study employed homogeneous purposive sampling. This method focuses on one specific subgroup in which all the sample members are similar. The target population for this study comprised Form 4 students from two schools. There were 100 students in the population, of whom 93 participated in the study. The two selected schools represented a school in the city and one in a rural area.

To answer the research question, participants were required to complete a questionnaire. This comprised three sections: Section 1 (A) gathered information on students' personal background through a demographic profile; Section 2 (B) collected information on students' preferences with respect to learning English; Section 3 (C) focused on students' perception of video usage in the classroom. The Likert scale designed for this questionnaire was as follows: " 1 " for strongly disagree, "2" for disagree, " 3 " for somewhat agree, " 4 " for agree, and " 5 " for strongly agree. The questionnaire was also translated into Bahasa Melayu (the Malay language).

The reliability test is a method for checking a scale's internal consistency. Cronbach's alpha is used as the indicator, the value of which should be above 0.7 . The overall Cronbach's alpha value for the instrument was 0.928. The constructs for all variables had a Cronbach's alpha coefficient of more than 0.9 . Face validity and content validity were also verified before data collection and reliability testing to ensure the validity of the instrument.

\section{Results and Discussion}

Technology has evolved rapidly over the years. The government has therefore instructed educators to integrate technology into teaching and learning processes. Video technology should be used, as it is one of the key interactive teaching methods. The findings (Table 1: Item $23)$ indicate that $88(94.7 \%)$ respondents strongly agree, agree and somewhat agree that video allows them to view material at their convenience; only $5(5.4 \%)$ respondents disagree and strongly disagree with the statement. The use of video is a convenience as long as users have their technology available, which can be a device such as a computer, a laptop, or even their mobile phones or smartphones. The most important requirement is to have a strong Internet connection. Thus, students need these two important items with them wherever or whenever they want to watch a video to learn a particular lesson. The 
video will remain available unless the owner literally deletes it from their account.

The findings (Table 1) also suggest that a majority of the respondents agree that video (edutainment video) creates an engaging sensory experience (Item 22) with 87 (93.6\%) respondents indicating they agree, strongly agree and somewhat agree with the item. This is most probably because the content of the video can improve their level of proficiency. With regard to the time spent watching videos, the findings from Item 1 indicate that 73 (78.5\%) respondents agree, strongly agree, and somewhat agree that they spend more than two hours per day watching videos. They use this time to watch videos that help to improve their studies and it motivates them to learn the language. The findings from Item 2 suggest that 79 (84.9\%) respondents agree, strongly agree and somewhat agree that they spend time watching video improves their studies. Even though Vlogs are not considered "academic", they can inspire viewers to work hard and produce a daily video. This will benefit them and potentially help them to earn money. The use of effects, elements, and animations in the video, especially educational videos, will ensure the viewers focus more on the lesson. Audiences can become so engrossed that they do not even notice the time passing. By watching videos from across the world, students can learn the correct pronunciation for words. Sometimes pronunciations from other countries can sound different; thus, students will grasp a considerable amount of useful information simply by watching video. It also motivates them to learn more, especially in relation to languages.

Table 1. Video usage in the classroom

\begin{tabular}{|c|c|c|c|c|c|}
\hline \multirow[b]{2}{*}{ Item } & \multicolumn{5}{|c|}{ Distribution of Responses $f(\%)$} \\
\hline & $\begin{array}{l}\text { 1- Strongly } \\
\text { Disagree }\end{array}$ & $\begin{array}{c}2- \\
\text { Disagree }\end{array}$ & $\begin{array}{l}\text { 3- Somewhat } \\
\text { Agree \& } \\
\text { Disagree }\end{array}$ & 4- Agree & $\begin{array}{l}\text { 5- Strongly } \\
\text { Agree }\end{array}$ \\
\hline 1. I spend more than two hours per day on video & 13(14.0) & $7(7.5)$ & $20(21.5)$ & $33(35.5)$ & $20(21.5)$ \\
\hline 2. I spend time to watch video that improve my studies & $7(7.5)$ & $7(7.5)$ & $39(41.9)$ & $27(29.0)$ & 13(14.0) \\
\hline 3. Video fosters deeper learning & $4(4.3)$ & $18(19.4)$ & $18(19.4)$ & $42(45.2)$ & 11(11.8) \\
\hline 4. Video makes learning fun & $1(1.1)$ & $5(5.4)$ & $23(24.7)$ & $36(38.7)$ & $28(30.1)$ \\
\hline 5. Video grabs my attention to learn about something & $4(4.3)$ & $0(0)$ & $22(23.7)$ & $33(35.5)$ & $34(36.6)$ \\
\hline 6. Video helps me to understand when learning new things & $1(1.1)$ & $6(6.5)$ & $31(33.3)$ & $35(37.6)$ & $20(21.5)$ \\
\hline 7. Video helps increase my imagination based on the contents & $1(1.1)$ & $7(7.5)$ & $25(26.9)$ & $46(49.5)$ & $14(15.1)$ \\
\hline 8. Video creates memorable visual images & $8(8.6)$ & $9(9.7)$ & $32(34.4)$ & $31(33.3)$ & $13(14.0)$ \\
\hline 9. Video decreases my anxiety in the classroom & $7(7.5)$ & $20(21.5)$ & $34(36.6)$ & 25(26.9) & $7(7.5)$ \\
\hline 10. Video decreases tension while learning in the class & $4(4.3)$ & $10(10.8)$ & $23(24.7)$ & $34(36.6)$ & $22(23.7)$ \\
\hline 11. Video enables me to learn many new things & $3(3.2)$ & $1(1.1)$ & $15(16.1)$ & $48(51.6)$ & $36(28.0)$ \\
\hline 12. Video makes learning languages easier & $1(1.1)$ & $5(5.4)$ & $24(25.8)$ & $38(40.9)$ & $25(26.9)$ \\
\hline 13. ...easy to search language learning materials & $2(2.2)$ & $3(3.2)$ & $20(21.5)$ & $44(47.3)$ & $24(25.8)$ \\
\hline 14. ...to help them learn new language & $2(2.2)$ & $6(6.5)$ & $21(22.6)$ & $39(41.9)$ & $25(26.9)$ \\
\hline 15....achieve language proficiency faster using video & $3(3.2)$ & $8(8.6)$ & $31(33.3)$ & $35(37.6)$ & $16(17.2)$ \\
\hline 16.... motivated to learn language when video is used & $3(3.2)$ & $11(11.8)$ & $31(33.3)$ & $31(33.3)$ & $17(18.3)$ \\
\hline 17. ... comfortable using video when learning a language & $0(0)$ & $10(10.8)$ & $32(34.4)$ & $34(36.6)$ & $17(18.3)$ \\
\hline 18. ...video to learn a language is worth the time & $2(2.2)$ & $9(9.7)$ & $31(33.3)$ & $39(41.9)$ & 12(12.9) \\
\hline 19. The use of video in learning a LL is worth the effort & $1(1.1)$ & $7(7.5)$ & $34(36.6)$ & $38(40.9)$ & 13(14.0) \\
\hline $20 \ldots$ fair even to the less technology-savvy students & $4(4.3)$ & $6(6.5)$ & $25(26.9)$ & $34(36.6)$ & $24(25.8)$ \\
\hline $21 \ldots$ video in LL does not add an extra burden & $3(3.2)$ & $4(4.3)$ & $25(26.9)$ & $42(45.2)$ & $19(20.4)$ \\
\hline 22. Video creates a more engaging sensory experience & $1(1.1)$ & $5(5.4)$ & $18(19.4)$ & $52(55.9)$ & $17(18.3)$ \\
\hline $23 . .$. to view at my convenience from wherever I am & $1(1.1)$ & $4(4.3)$ & $17(18.3)$ & $34(36.6)$ & $37(39.8)$ \\
\hline 24. Video increases my knowledge retention & $0(0)$ & $3(3.2)$ & $22(23.7)$ & $40(43.0)$ & $28(30.1)$ \\
\hline 25. Video increases my digital literacy & $2(2.2)$ & $5(5.4)$ & $29(31.2)$ & $44(47.3)$ & 13(14.0) \\
\hline 26. Video increases my digital communication & $4(4.3)$ & $6(6.5)$ & $22(23.7)$ & $44(47.3)$ & $17(18.3)$ \\
\hline $27 \ldots$ creates more engaging sensory experience for me & $2(2.2)$ & $7(7.5)$ & $24(25.8)$ & $46(49.5)$ & $14(15.1)$ \\
\hline 28. ... assistance when I learn a complex subject & $4(4.3)$ & $8(8.6)$ & $20(21.5)$ & $44(47.3)$ & $17(18.3)$ \\
\hline $29 . . .$. assistance when I learn a highly procedural subject & $0(0)$ & $5(5.4)$ & $19(20.4)$ & $44(47.3)$ & $25(26.9)$ \\
\hline 30. Video gives me great assistance in learning any subject & $1(1.1)$ & $3(3.2)$ & $24(25.8)$ & $37(39.8)$ & $28(30.1)$ \\
\hline Video increases student engagement with the materials & $0(0)$ & $4(4.3$ & $18(19.4)$ & $45(48.4)$ & $26(28.0)$ \\
\hline
\end{tabular}


The usage of video specifically edutainment is improving daily and educators are now taking the initiative to help their students enhance their concentration while at the same time assisting them to understand the lesson better. Video usage has several merits and few demerits. Previous and present research has indicated that video fosters deeper learning, increases understanding when learning new things, increases the use of imagination based on the contents, and creates memorable visual images. The usage of video in the classroom also affords students a chance to immerse themselves into the content. For instance, although they may never have been to a particular country, they can simply watch the video to appreciate what this country is like. It enables them to learn about the people, the culture, and the language of a particular country without needing to travel. The findings for Item 7 indicate that video helps increase imagination based on the contents as $85(91.5 \%)$ respondents agree, strongly agree, and somewhat agree with the item. The finding is consistent with the results of a previous study [13].

The findings for Item 4 indicate there was only one respondent $(1.1 \%)$ who strongly objected to the use of video to make learning enjoyable; almost all the respondents perceived otherwise. Educators always need to improve their teaching skills so that students are engaged and focused on the lesson. One strategy is to ensure the teaching and learning process is always up-to-date. In so doing, the most important consideration is to ensure the materials used are relevant to modern education and are enjoyable for students to learn. The choice of materials is extremely vital because this will determine the success of the teaching and learning process. The use of video should become essential for teachers in order to make the teaching and learning process enjoyable in a technologically advanced world.

Krishnasamy [14] reported in New Straits Times (NST) on 30 October 2015 that one of the editors, Mustapha Kamil, had underlined the importance of teachers bringing creativity into the English language classrooms and not being overly dependent on textbooks or materials provided in schools. Mustapha Kamil described his experiences learning English during his school days, which included watching movies. According to the present findings, 87 out of 93 respondents $(93.5 \%)$ agree, strongly agree and somewhat agree that video makes learning enjoyable. Dependency on the textbooks or materials provided in schools was no longer seen as relevant and does not enhance the credibility of educators. Teachers need to challenge themselves to prove they are worthy of being educators. The entertaining part of learning will flourish as creativity is introduced into the teaching and learning process, especially in the classroom.

A five-point Likert scale ranging from 1 - strongly disagree to 5 - strongly agree was also used to measure the level of video usage among Form Four (4) students. Respondents who scored 1 to 2 were considered to have a low level of video usage, 3 a moderate level of video usage, and 4 to 5 a high level of video usage.

Table 2. Level of video usage among secondary school students

\begin{tabular}{|c|c|c|c|c|c|}
\hline & & Frequency & Percent & $\begin{array}{c}\text { Valid } \\
\text { Percent }\end{array}$ & $\begin{array}{c}\text { Cumulative } \\
\text { Percent }\end{array}$ \\
\hline \multirow{4}{*}{ Valid } & High & 54 & 58.1 & 58.1 & 58.1 \\
\cline { 2 - 6 } & Moderate & 20 & 21.5 & 21.5 & 79.6 \\
\cline { 2 - 6 } & Low & 19 & 20.4 & 20.4 & 100.0 \\
\cline { 2 - 6 } & Total & 93 & 100.0 & 100.0 & \\
\hline
\end{tabular}

Table 2 presents the level of video usage among secondary school students. This shows that 54 respondents or $58.1 \%$ have a high level of video usage, 20 respondents, $21.5 \%$ have a moderate level of video usage, and only 19 respondents, or $20.4 \%$ have a low level of video usage. This means that majority of the respondents reported a high or moderate level of video usage. This study also determined whether there was a significant difference in the level of video usage based on school area. An independent t-test was used to compare the means of students living in city and rural areas. Table 3 and Table 4 present the differences in the level of video usage according to school area.

Table 3. Descriptive statistics for video usage by school area

\begin{tabular}{|l|l|l|l|c|c|}
\hline & SA & $\mathrm{N}$ & Mean & Std. Deviation & $\begin{array}{c}\text { Std. Error } \\
\text { Mean }\end{array}$ \\
\hline $\begin{array}{c}\text { Level of } \\
\begin{array}{c}\text { Video } \\
\text { Usage }\end{array}\end{array}$ & City & 38 & 1.6316 & .78572 & .12746 \\
\cline { 2 - 6 } & Rural & 55 & 1.6182 & .82756 & .11159 \\
\hline
\end{tabular}

Table 4. Differences in video usage by school area

\begin{tabular}{|c|c|c|c|c|c|c|c|c|c|c|}
\hline & & \multicolumn{2}{|c|}{$\begin{array}{l}\text { Levene's Test } \\
\text { for Equality of } \\
\text { Variances }\end{array}$} & \multirow[b]{2}{*}{$\mathrm{t}$} & \multirow[b]{2}{*}{ df } & \multirow[b]{2}{*}{$\begin{array}{c}\text { Sig. } \\
\text { (2tailed) }\end{array}$} & \multicolumn{2}{|c|}{$\begin{array}{l}\text { t-test for Equality of } \\
\text { Means }\end{array}$} & \multicolumn{2}{|c|}{$\begin{array}{c}95 \% \\
\text { Confidence } \\
\text { Interval of the } \\
\text { Difference }\end{array}$} \\
\hline & & $\mathrm{F}$ & Sig & & & & $\begin{array}{c}\text { Mean } \\
\text { Difference }\end{array}$ & $\begin{array}{l}\text { Std. Error } \\
\text { Difference }\end{array}$ & Lower & Upper \\
\hline \multirow{2}{*}{$\begin{array}{c}\text { Level of } \\
\text { Video } \\
\text { Usage }\end{array}$} & $\begin{array}{c}\text { Equal } \\
\text { variances } \\
\text { assumed } \\
\end{array}$ & .355 & .553 & .078 & 91 & .938 & .01340 & .17104 & $\begin{array}{c}- \\
32634\end{array}$ & .35314 \\
\hline & $\begin{array}{c}\text { Equal } \\
\text { variances } \\
\text { not assumed }\end{array}$ & & & .079 & 82.319 & .937 & .01340 & .16940 & $\begin{array}{c}- \\
32358\end{array}$ & .35038 \\
\hline
\end{tabular}


$\mathrm{Ho}_{1:}$ There is no relationship between school area and the level of video usage.

The area in which a school is located has always been an excuse for teachers and students not to use technology. Teachers have complained that they experience difficulty using the technology in the teaching and learning process. However, over the years the government has provided facilities such as laptops, projectors, and even the Internet to each school, including those in rural areas, to provide better educational experiences for all students. For instance, the Ministry of Education has spent more than RM 6 billion on ICT over the past decade - in education initiatives [4]. Although some facilities may still be lacking, there is no excuse not to use technology. Schools in both urban and rural areas receive the same provisions in terms of facilities from the government to involve teachers and students in the use of technology and, most importantly, maximize the usage of video in the classroom.

This research has found no significant relationship between school area and the level of video usage. This is because even those respondents living in a rural area can easily access the Internet without any trouble. The findings also indicate that most respondents access videos using their own smartphones and the Internet using their own mobile data. They utilize the Internet to watch videos either in the classroom or outside. Even though most of the respondents are from rural schools, the results still indicate a high level of video usage. This demonstrates that, regardless of their location, secondary school students can watch and enjoy videos. However, the findings contrast with research conducted by [15] in Masvingo, Zimbabwe, which found that students in city areas reported significantly higher levels of video usage than students in rural areas where computers were nothing more than decorations. There are several possible reasons for this discrepancy in the findings. The first may be that there were more respondents from rural schools than from city schools in this study. Therefore, the results might not have been very precise in representing a particular school area. Another possible reason could be that respondents might have given the answers based on their feeling at a particular time even though this is not how they feel in actual learning situations or in their daily lives.

According to Levene's Test, if $p>.05$, it means the two variances are approximately equal. No significant differences were observed in the scores for rural $(\mathrm{M}=1.63$, $\mathrm{SD}=0.79)$ and city $(\mathrm{M}=1.62, \mathrm{SD}=0.83)$ respondents. The Independent Samples Test results (Table 5) indicate that $\mathrm{p}=.94$ is greater than 0.05 , and therefore no significant difference was found in the reported level of video usage between city and rural area conditions (t $(91)=.078$, p $=.94)$. The data provides sufficient evidence to reject $\mathrm{Ho}_{1}$ $(p>0.05)$. Thus, the hypothesis that there is no significant difference between city and rural areas with regard to level of video usage is supported. This means that city and rural students are likely to display a similar amount of video usage.
Because the level of video usage depends on students' access to facilities, this is the most important factor in determining whether they can watch videos. Without facilities, students will have a problem accessing videos on their own. The findings in the present research indicate a statistically significant relationship between students' access to facilities and the level of video usage. The findings are consistent with those by other researcher [16] in a sample of senior high school students in Ghana which found that most students in rural areas have access to mobile phones.

Similarly, the current findings also revealed that most students use their smartphones to watch videos as 68 out of 93 respondents $(73.1 \%)$ owned the device. This finding is not surprising somehow as even children at present also have the access to smartphones as parents tend to give their child the gadget as a way to stop them from crying or to stop them from causing disturbance while working. Therefore, they were exposed to the smartphone ever since they were still young. At this current point in time, when the COVID-19 pandemic is forcing schools to close down, numerous countries, including Malaysia, are resorting to online learning with substantial video usage, which means children will need to have access to their parents' devices. All houses today must have at least one gadget. It is now seen as normal for almost all respondents to use their smartphones to watch videos and engage in a wide range of other activities. For instance, parents now use their smartphones to show their infant children videos such as Didi and Friends, Boboiboy, Upin \& Ipin, and other similar edutainment videos.

Table 5. Descriptive statistics of facilities used

\begin{tabular}{|c|c|c|c|c|c|}
\hline \multirow{1}{*}{} & & Frequency & percent & $\begin{array}{c}\text { Valid } \\
\text { percent }\end{array}$ & $\begin{array}{c}\text { Cumulative } \\
\text { percent }\end{array}$ \\
\hline Valid & Laptop & 15 & 16.1 & 16.1 & 16.1 \\
\cline { 2 - 6 } & $\begin{array}{c}\text { Smart } \\
\text { phones }\end{array}$ & 68 & 73.1 & 73.1 & 89.2 \\
\cline { 2 - 6 } & $\begin{array}{c}\text { Pearson } \\
\text { Computer }\end{array}$ & 3 & 3.2 & 3.2 & 92.5 \\
\cline { 2 - 6 } & $\begin{array}{c}\text { School } \\
\text { Computer }\end{array}$ & 6 & 6.5 & 6.5 & 98.9 \\
\cline { 2 - 6 } & Others & 1 & 1.1 & 1.1 & 100.0 \\
\cline { 2 - 6 } & Total & 93 & 100.0 & 100.0 & \\
\hline
\end{tabular}

Table 6. Pearson correlation test comparing student access to facilities with level of video usage Correlations

\begin{tabular}{|c|c|c|c|}
\hline \multirow{2}{*}{$\begin{array}{c}\text { Student Access } \\
\text { to Facilities }\end{array}$} & $\begin{array}{c}\text { Students } \\
\text { Access to } \\
\text { Facilities }\end{array}$ & $\begin{array}{c}\text { Level of } \\
\text { Video } \\
\text { Usage }\end{array}$ \\
\cline { 2 - 4 } & Pearson Correlation & 1 & $.220^{*}$ \\
\cline { 2 - 4 } & Sig. (2-tailed) & & .034 \\
\hline \multirow{2}{*}{$\begin{array}{c}\text { Level of Video } \\
\text { Usage }\end{array}$} & Pearson Correlation & $.220^{*}$ & 1 \\
\cline { 2 - 4 } & Sig. (2-tailed) & .034 & 93 \\
\cline { 2 - 4 } & $\mathrm{N}$ & 93 & 93 \\
\hline
\end{tabular}

*. Correlation is significant at the 0.05 level (2-tailed). 
The Pearson Correlation Test results identified a statistically significant relationship between student access to facilities and the level of video usage $(r=.22, p<0.05)$. While access to technology can provide valuable learning opportunities to students, it does not guarantee successful outcomes. Nevertheless, without access to technology for video usage there is no point in designing and developing excellent technology. This is supported by the National Center for Education Statistics on student access to digital learning resources outside the classroom report [17].

\section{Conclusions}

This research has shown that the majority of the respondents loved watching videos as they spend more than two hours per day doing so. English teachers in the classroom should consider this, as many of the students' responses in this study were positive. The findings of this study are useful, not only for English teachers working in a school, but also to lecturers in the same field. Because there are different types of students, this study will be beneficial for educators in understanding what their students' preferences are with respect to learning English. As the world continues to evolve, educators should be capable of introducing a more stimulating and dynamic range of teaching techniques. Similarly, policy-makers can utilize this study to consider a range of additional strategies that can be implemented as part of 21 st-century education to help both educators and students. For instance, collaboration with administrators, educators, students, parents and other policy-makers will help ensure the education syllabus is updated with 21st-century educational practices. Most importantly, the government should also provide classes with an adequate number of computers connected to the Internet as this will make it easier for students to access videos and ensure a more effective teaching and learning process.

\section{Acknowledgement}

The study was supported by grants from the Faculty of Education and Universiti Kebangsaan Malaysia which are GG-2019-046, GUP-2020-020 and PP-FPEND-2020.

\section{REFERENCES}

[1] Almurashi, W.A, "The effectiveness use of YouTube videos for teaching English language in classrooms as supplementary material at Taibah University in Alula", 4. 32-47. Online. Research Gate, 2016.

[2] Ebrahimi, S.S, Yeo, K. J, "The Use of Technology at Malaysian Public High Schools," Merit Research Journals, vol. 3, pp. 54-60, 2018. Retrieved July 30, 2020 from http://meritresearchjournals.org/asss/index.htm.

[3] Ya Shin Wan, "Education during COVID-19," Brief Ideas, Vol. 19 (April), pp. 3-9, 2020. Retrieved July 30, 2020 from https://www.researchgate.net/publication/340860261_Educ ation_during_COVID-19

[4] Ministry of Education, Executive Summary Malaysia Education Blueprint 2013-2025 (Higher education), 2015

[5] Muniandy, V, "Effectiveness of flipped classroom on students' achievement and attitudes towards English language in secondary school", 2018, Universiti Sains Malaysia.

[6] Rajhi, Amaal, "Using multimedia presentations in teaching (videos, films) in Oman: A cause study of a primary school," Journal of teaching and education, vol. 5, pp. 127-136, 2016

[7] Rozana Sani., "Innovative teaching at universities," New Straits Times, Jan 16, 2019

[8] Siti Hadijah, "Teaching by using videos: Ways to make it more meaningful in EFL classrooms", Proceedings of ISELT FBS Universitas Negeri Padang. Research Gate, 2016

[9] Tan, C.K., Lee, K. W., Radim, S. M, "Learning English language with technology: Case study of a primary school in Kota Belud, Sabah," The International Journal on E-Learning Practices (IJELP), vol. 3, no. 1, 2016

[10] Noha Halwani, "Visual Aids and multimedia in second language acquisition," English language teaching, vol. 10, no. $6,2017$.

[11] Siew, M.T., Kean W.L., Murugaiah, P., Jaafar, N.M., Tan, C. K., Bukhari N.I.A, "ICT tools patterns of use among Malaysian ESL undergraduates," Gema Online Journal of Language Studies, vol. 16, no. 1, 2016

[12] Dudovskiy, J, The Ultimate Guide to Writing a Dissertation in Business Studies: A Step-by-Step Assistance. First Edition, 2016

[13] Ismail, M.E., Irwan, M.I., Othman, H., Amiruddin, M.H., Ariffin, A, "The use of animation video in teaching to enhance the imagination and visualization of students in engineering drawing," IOP Conference Series: Materials Science and Engineering. 19-20 April, Politeknik Metro, Johor Bahru, 2017. Retrieved July 30, 2020 from https://iopscience.iop.org/article/10.1088/1757-899X/203/1/ 012023.

[14] Krishnasamy, H. N, "Creativity needed in the classroom", New Straits Times, 30 October, 2015

[15] Musingafi, M.C.C., Chaden'anga, C, "Information and communication technology in classroom situations in rural and urban areas in Zimbabwe: a comparative study on the use of digital and projected media in teaching and learning at six secondary schools in Masvingo," Review of Information Engineering and Applications, vol. 1, no. 4, pp. 77-92, 2014

[16] Donkoh, F. A., "Impact of social media on Ghanaian High School students", Library Philosophy and Practice (e-journal), 2018

[17] National Center for Education Statistics. Student access to digital learning resources outside the classroom. NCES 2017-098, 2018. Retrieved October 24, 2020 from https://nces.ed.gov/pubs2017/2017098/index.asp. 